\title{
鉄道車两に対するファジイ推論を 用いた滑走防止制御の性能向上十
}

\author{
野中 俊昭*1・遠藤 靖典 $* 2 \cdot$ 吉川 広*3
}

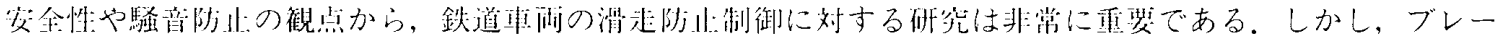

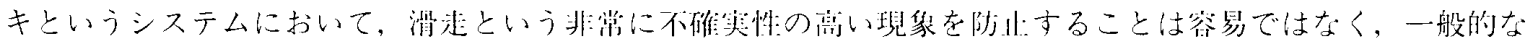

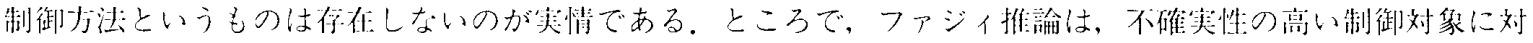

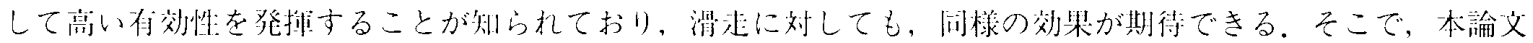

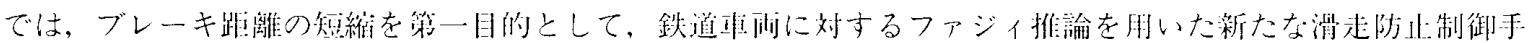

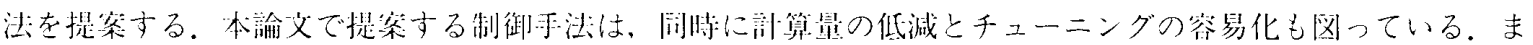
た，数做シミュレーションを通して，提案する制御于洁によってブレーキ趾離の短維が实現されていることを 示吉。

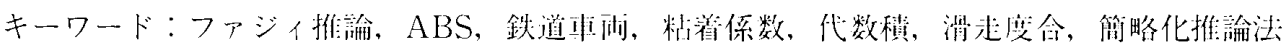

\section{1 はじめに}

鉄道車再では，降雨時などにおけるブレーキで直輪 が滑走・固着（事輪の完全停止）することがあるが， これは，以下の 2 点の閣題を生む.

(1)ブレーキ距離を延ばす.

(2)車輪踏䤄が椇䅞する。

(1)の問題は，急停此を阻むばかりでなく，列東遈㢟 にも繫がるため，等金百からも輸送サービス而からも 大きな闍題である。(2)の間題は，走行侍における䮎意 や振動の大きな原因となることから，沿線に刘する環 境䦥題に繫がる.

また，滑术という物理現象は，レールと本輪の䦌の 摩擦を俳うが,接触面の粗さやレールにの水膜の厚さ, 活れ，温度など，定量的に特等子ることが困難な多く の装因に依存した現象であるため，不確声性が非常に 高い。一方，こうした不確䈍性の高い制御刘象に対し

† Improvement of Control Performances of Anti-Lock Braking System with Fuzzy Reasoning for Rolling Stock Toshiaki NONAKA, Yasunori ENDO, Hiroshi YOSHIK. AWA

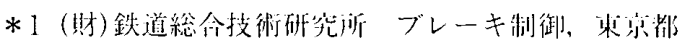

Brake Control,Railway Technical Research Institute, Tokyo 185-8540, Japan

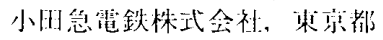

Odakyu Electric Railway Corporation, Tokyo 160-8309. Japan

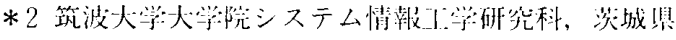
Faculty of Systems and Information Engineering, University of Tsukuba, Ibaraki 305-8573, Japan

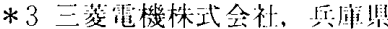

Mitsubishi Electric Corporation. Hyogo 661-8661, Japan

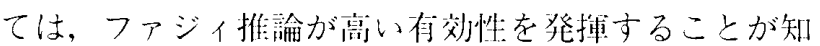
られている。

そこでこれまで，滑走防止制御(以下，ABS)につい ての研究・開発が活発に行われ[1]〜 [12]，(1)および(2) の䦌題に対して一定の成果をあげているが，その中で も特に，ファジィ推論を朋いた ABS(以下，ファジィ ABS) [1]～[3]が高い成果老あげている。

ところで, ABSによって(1)および(2)の問題を同時に 解沃することは，困難である。車輸損鹪を低減するた めにはできるだけ滑走を許容しないすが良いが，ブレ 一キ趾離を短維するためには洞走をある程度竍容する

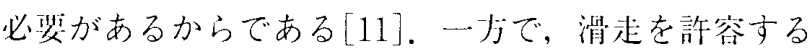
と，固着に等るリスクが高まる。したがって，軦輪損 㑺の低減に比べて，ブレーキ践離の短維を図ることは 穴易ではなく、ファジィ ABS を含め,ブレーキ距離の 知維を洞る余地は大きいのが萡情である。

そこで本論文では，制御刘象の特徴を踏まえ，ブレ 一キ距墔の短維を第一目的とした, 新ななファジィ ABS

（以下，新什様）を提案する。新仕様は，現在用いら れているファジィ ABS (以下，現状仕様）に比べ，計 算㻎の低減とチューニングの空易化も図っている。ま た，数脩シミュレーションにより，新仕様では現状仕 様よりもブレーキ距離の短維が実現されていることを 示古。

\section{2 鉄道車両の機械ブレーキ}

\section{1 機械ブレーキシステムの概要}

鉄道車两の機械ブレーキは一般に，「運転士の操作」 (または「ATCなどの保发装䈯からの指令」)と「乗車 


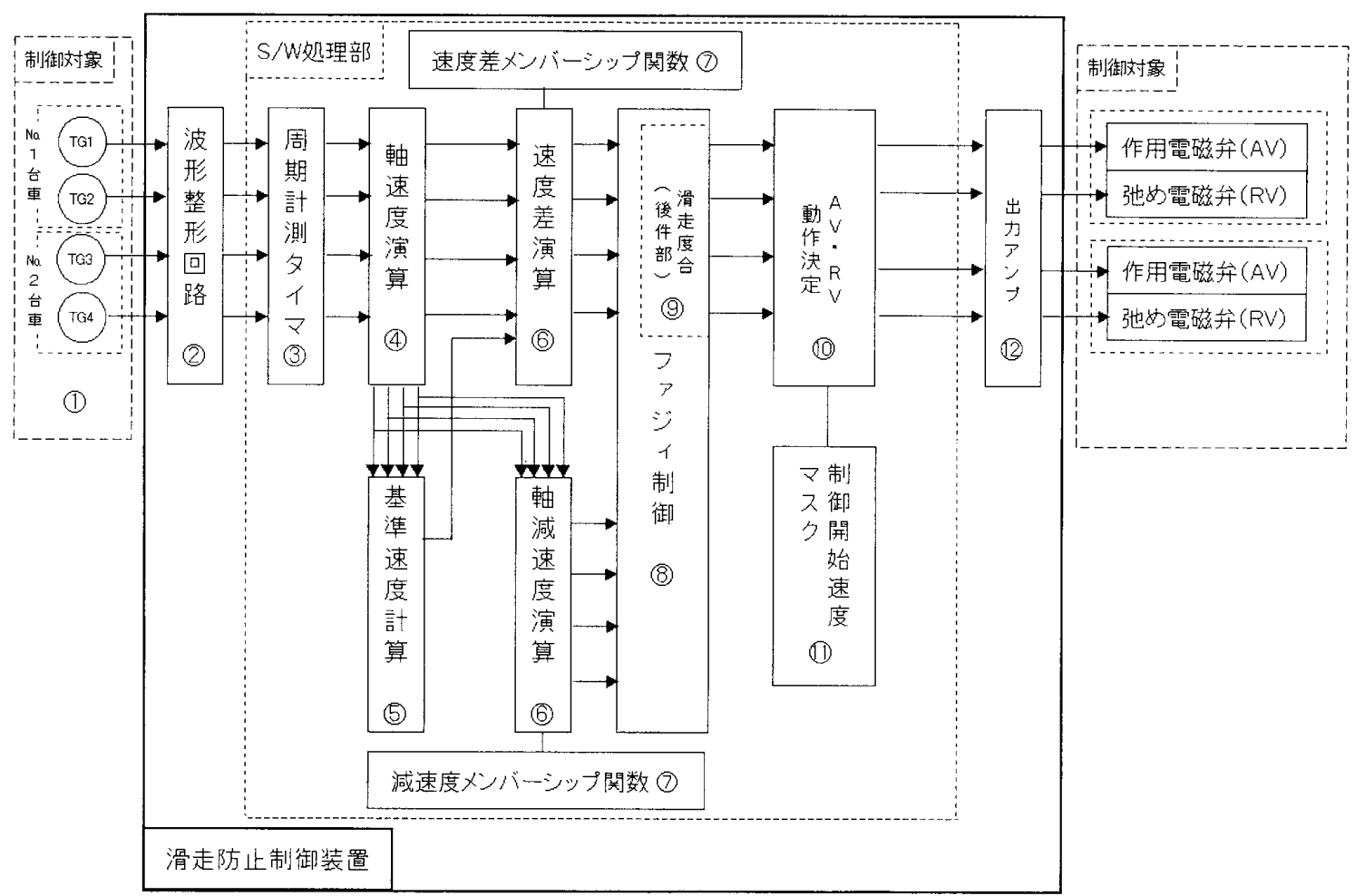

図1ファジィ推論を用いた ABSブロック図

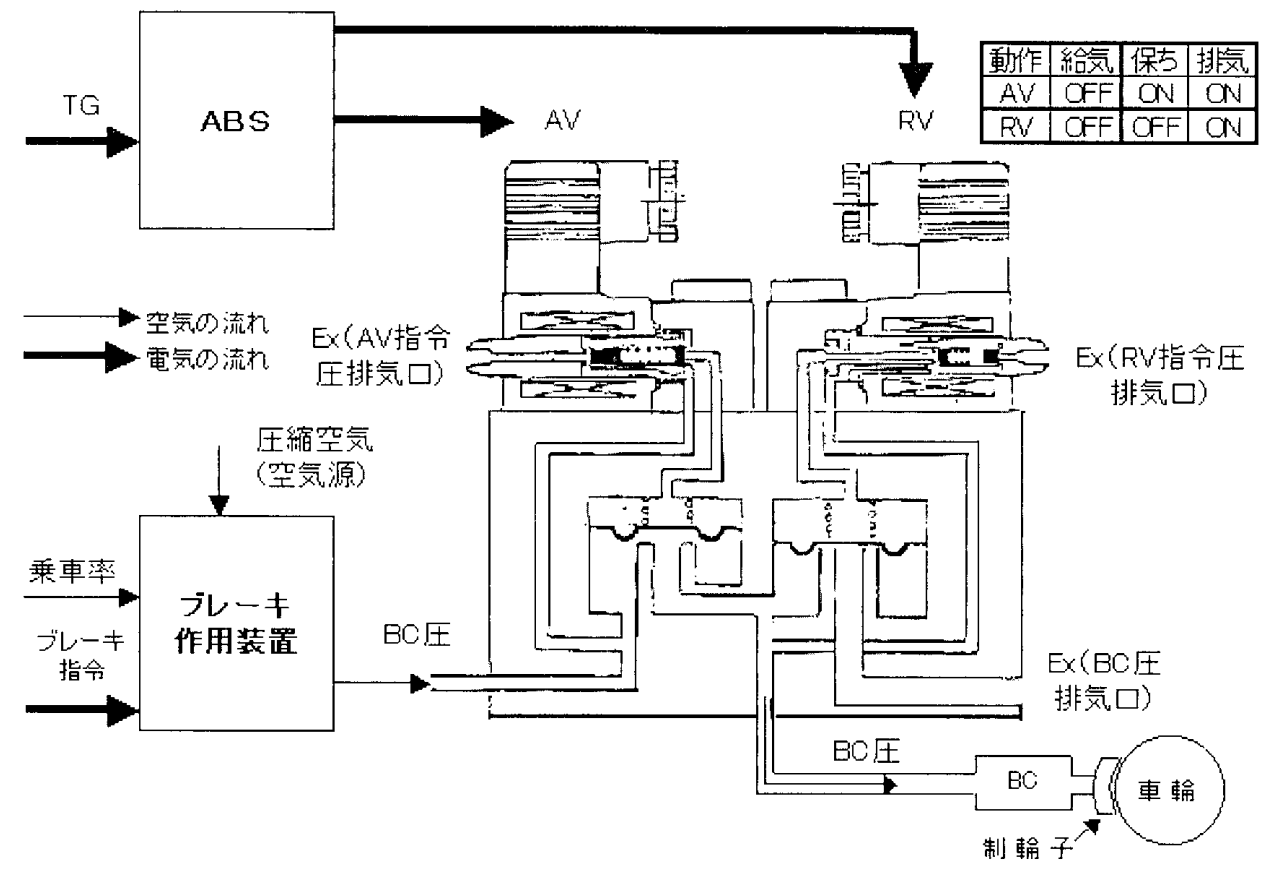

図2 BC 圧の流れ

率」に応じた圧縮空気を $\mathrm{BC}$ (ブレーキシリンダ)に込 めることで車輪踏面に制輪子を押し付けている。この 押付力と事輪・制輪子間の摩擦係数との積である摩擦 力を,ブレーキ力として車軸単位 (各軸 2 車輪)に与之, 編成としての減速度を生み出している。なお，鉄道車 両の減速度は最大で $4.5 \sim 5.0 \mathrm{~km} / \mathrm{h} / \mathrm{s}$ 程度である。

一方，降雨時など，レール面が滑りやすい状態のと きに大きなブレーキ力を与えると, 車輪が滑走・固着
してしまう。鉄道車両の ABSでは, 各車軸に TG(速 度発電機)を設置し各車軸の速度と加減速度を常時算出 することで滑走を検知し， $\mathrm{BC}$ 压 (BCに込めた学気压 力）を $\mathrm{AV}$ (作用電磁弁) と RV (弛为電磁弁)の $2 つ 0$ 電磁弁により速やかに給排気させてブレーキ中の滑走 防止を図っている。具体的には, $\mathrm{AV}$ は $\mathrm{ON}$ 状態で $\mathrm{BC}$ 压の入力を締为切る電磁弁であり, RV は $\mathrm{ON}$ 状態で $\mathrm{BC}$ 压を排気させる電磁弁である。従って，通常走行時に 
は AV，RVとも OFF 状態（給気モード）であるが， 滑走を検知した際には，AV，RVとも ON 状態(排気 モード)とすることで BC压を速やかに減压させる。そ の後滑走が改善してくると，AVを ON 状態，RVを OFF 状態(保ちモード)とすることでその侍点での BC 压を維持させ，さらに滑走が改善し通常走行に国復し はじめると $\mathrm{AV} ， \mathrm{RV}$ とも $\mathrm{OFF}$ 状態（給気モード）と することで,本来のブレーキ力となるよう BC压を元の 王力まで給気する。

図 1 にはABSのシステム構成例として,ファジィ推 論を用いた ABSのブロック四を、四 2 にはBC 压の流 れを示方。なお，ABSの制御単位は一般に 1 㳡=4 本 軸である。

\section{2 レール・車輪間の粘着係数}

鉄道車陠のブレーキ力・加速力は，レール而を本輸 が転がる接触面で発生する接線方向の力により得られ る。この接線方问の力は粘着力と呼ばれ，正常状態で は静摩擦的な特性を, 滑走・空転・固着状態では動摩 擦的な特性をそれぞれ示す。またこのレール・車輸 間の粘着力は，輪重（車輪にかかる重量）とレール・車 輪間の粘着係数により決定される(四 3 参照)。なお， 粘着係数は，厳密には，滑走に至る前の最大粘着力を 輪重で除した值を指寸が, 本論文では, 滑走時を含め, 粘着功を輪重で除した储を指すものとする。

一方，設棓段階では，押付力から得られるブレーキ 力を，設計上の輪重と粘着係数から算出される粘着力 以下となるように浃めているがレール・車輪間の粘 着係数は特に变動が激しく, 降雨侍には粘着係数が設 計傎を大きく下四ることがある。このため，滑走を発 生さないためにはいかに粘着係数の低下を防ぐかが重 装である。

降丽時の粘着係数は車雨の走行速度と車輸のすべり 率 $(=$ (走行速度一自軸速度 $)$ /走行速度) に依存寸る ことが知られており，高速域ほど，また巨视すべり領 域(すべり莝が $0.5 \%$ 程度以上の状態で，動摩擦们な特 性を示す領域)においては，すべり率が大きくなるほど， 粘着係数は低下寸る倾们がある。しかしながらこの傾 向は、レールと車輪の接触䤄の粗さや水膜の厚さ、レ

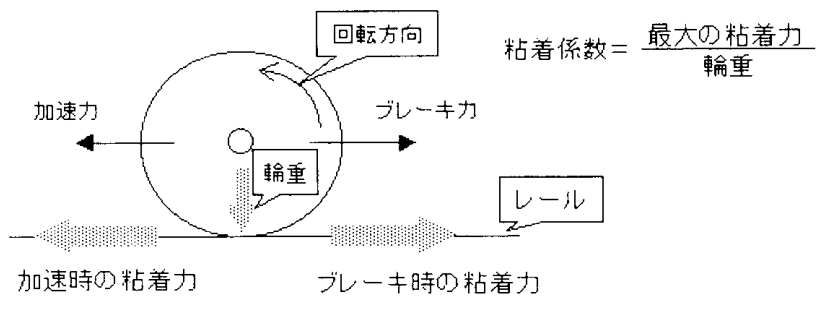

図3ブレーキ力・加速力と粗着力の咸係
一ル面の汸れ，温度などによって大きく变化してしま う。また，巨視すべり領域において，すべり率が $20 \%$ 程度までは,レール・車輪間の摩擦による仕事の影響 で，水膜の除去と車輪踏面の粗面化のために，粘着係 数が㗔やかに上暑するという試験結果も報告されてい る [11], [13].

一方，複数車闲の編成として見た場合，光頭の車輸 ほどレール陑における水膜の影響を受け，後続の車輪 ほど水膜の影響が薄れる。ささらに，前の車輪が滑走す ると水膜の除去效果が高まり, 後続の車輪は一層滑走 しにくくなることも知られている。

これらのことから，滑走は，粘着係数のばらつきの た加に非常に不確実性の高い現象であると言える。ま た、ファジイ推論を用いたものを含め, 鉄道車両の ABS では，特に高速域においてある程度の滑走を許容させ る設計をしている場合が多い[4], [5], [11]〜 [14]．

\section{3 現状仕様と新仕様}

\section{1 現状仕様}

ファジィABSは，1990年代はじめに開発・策用化さ れ，在来線を中心とした鉄道車両に採用されている[1] 〜 [3]. 以下に, 図 1 に基づき, 現状仕様のファジィ推 論部の詳細について示す。

[手順 1 ] (図 1 -(5)

基集速度を算出する。なおここでいう基集速度とは， ABS の制御で使う走行速度のことであり, ABS 制御対 俰(一般に 4 車軸)に含まれる各軸の速度と, 減速度 6.5 $\mathrm{km} / \mathrm{h} / \mathrm{s}$ として伋想的に算出寸る速度のうち最大速度の ものとする，基準速度は，实際の車両の走行速度と同 储ではない。

[手順 2](図 1-6)

各軸の速度と基隻速度から, 各軸の『速度差』と『減 速度』を下式により算出卞る。

速度差:基蕉速度一自軸速度

減速度二（自軸速度の前回演算值一自軸速度の今回 渲算做) /演算周期

[手順 3 ] (図 1 -(7)

前件部として，罒40ようなメンバーシップ関数を設 䇥しておき，各軸の『速度差』と『減速度』のグレー ドを算出する。

[手順 4 ] (図 1 -8)

『速度善』AND『減速度』 $\Rightarrow$ 『滑走度合』からなる図 6 の制御規則を構成することで『滑走度合』を推定す る。なお，前件部 AND，含意規則 $(\Rightarrow)$ と， min を用 いる.

[手順 5 ］(四 1 -99)

後件部『滑走度合』に対して,ファジィ集合として図 
5のようなメンバーシップ関数を設定しておく.なお， 推論形式は「min-max 合成」であるが, 非ファジィ化 は重心法ではなく四 7 のような簡略化推論法に近い力 法としている。非ファジィ化して得られた『滑走度合』 は 0 6000間の值をとり，300で「保ち」，300より大 きいと「排気」，300より小さいと「給気」とする。

[手順 6]（四 1-(10)

非ファジィ化して得られた『滑走度合』より，AV, RV の $\mathrm{ON} / \mathrm{OFF}$ を決定する。この $\mathrm{AV}, \mathrm{RV} の \mathrm{ON} / \mathrm{OFF}$ の 決定は，『滑走度合』を削件部，『弁の ON/OFF』を後 件部としたファジィ推論により行って抢り, 手順 4 と 合わせ，多段ファジィ推論を構成している。

[手順 7]（汹 1-(11))

「高速域での滑走を許容させること」と「外乱による 弁の鿁動作防止」を主な目的として，一定の速度差が 生じるまで弁を動作させない(制御出打をマスクする) よう，基準速度に忍じて网 8 のような制御開始速度差 を設楚する。

なお，現状仕様では，国着防止を微底するためにひ とつの滑走侍間をできるだけ短くすることを優光し， そのためには, 必ずしもファジイ推論による推論結果 に惢奏に出打する必要はないものとしている。そのた めに後件部のパラメー夕設定と合わせ，制御開始速度 㠻老制御出力に活用している。

\section{2 新仕様}

新仕様について，以下(1)〜 (6)に示す.

(1) 解件部『速度差』の代わりに『すべり率』を用い る (図 4 参照)。

この理由は，以下の 2 点である。

(1)レール・車輪間の粘着係数は『すべり率』に依存 するため，前件部に『速度差』を朋いると，車両 の速度域に応じて検知感度が筫なってしまう。

特に，滑走すると固着に至りやすい低速時におい
て，検知感度が低下してしまう。

(2)全轆滑走時，制御で用いている走行速度と实際の 走行速度は同一とならないため，『速度着』も『す べり率』も制御で用いる值と実際の值とで愦差が 生じるが，その䛊差割合は『速度差』の方が『㐫 べり率』よりも大きい.

(2) 前件部から VPM, BPM を削除し, BNS, BNM, $\mathrm{BNB}$ を $\mathrm{BN}$ に統合する(前件部パラメー夕を 9 個 $\Rightarrow$ 5 個, 制御規則を 28 個 $\Rightarrow 12$ 個にそれぞれ削減, 四 4 , 6 参照).

この理由は，以下の 2 点である。

(1)現状仕様では，前件部にVPM, BPM(減速度中, 速度着中) を設定しているが, 人間の感覚として減 速度やすべり率の大-中-小の 3 段階選別は難しい う之，滑走が回復していく過程（再粘着過程）で ある BNS, BNM, BNB (加速度小一中一大) は，制 御上，細分して緻密に制御子るほどの状態ではな w.

(2)現状仕様では，前件部パラメー夕，制御規則がそ れぞれ9個，28個と多く，チューニングが難しい。

（3）前件部『減速度』のBZOを三角形から台形に变更 する。(四 4 参照)

この理由は，三解形の場合， $4.5 \mathrm{~km} / \mathrm{h} / \mathrm{s}$ 程度以下 の, 減速度が司常なブレーキ中であるにも関わらず， BPS（滑走小）のグレードが現れてしまうためであ 万.

(4) 前件部 ANDの演算子を $\min$ から代数積に変更子 る(四 7,9 参照)。 この理由は，以下の 2 点である。

(1) minは強い非線形性を持つため，一般に代数積の 万が高い制御性能を示す場合が多い[15].

(2)代数積は，後件部老算出する際に分母が常に1と なる $[15] 〜[17]$ た，演算回数の低減にも貢献す る.

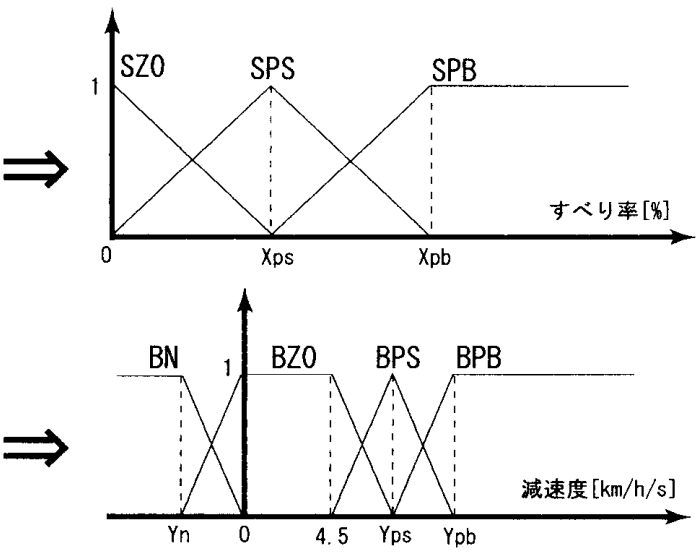

(2) 新仕様

図4 前件部メンバーシップ関数 
なお，前件部 ANDの演算子として限界積を比較 対眊としないのは，2つの前件部のグレードがす べて0.5近傍となった梤合, 限界積の演算結果が 0 近傍となることから，すべての制御規剘で後件部 のグレードが 0 近傍となり制御不能となる恐れが あるためである。図 9 -(1)（3)老比較しても限界 積のグラフには滑らかさがなく, 制御の不灾定さ が確認できる。

（5）後件部『滑走度合』をシングルトンとし，䉮略化 推論法老用いる(四 5 参照)。
この理由は, 以下の 2 点である。

(1)現状仕梯では，後件部『滑走度合』をファジィ集 合としているが，人間の感覚として『滑走度合』 をファジィ集合で表現することは不自然なうえ， 紝果啲に後件部の設定の自由度を奪っている。

(2)現状仕様における非ファジィ化の計算方法は簡略 化推論法に近いことから，後件部をファジイ集合 にしているメリットが头われているうえ，簡略化 推諭法よりも計算量は多くなっている。

（6）制御開始速度差による制御出力マスク領域を大幅

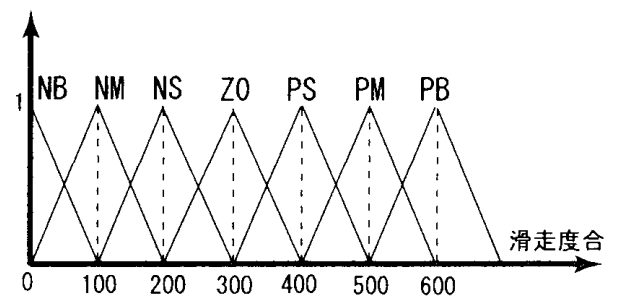

(1) 現状仕様

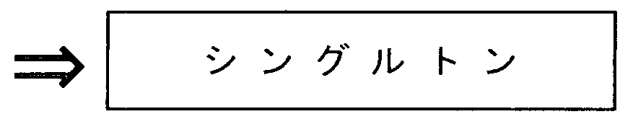

(2) 新仕様

図 5 後件部メンバーシップ咸数

\begin{tabular}{|c|c|c|c|c|c|c|c|}
\hline & BNB & BNM & BNS & BZO & BPS & BPM & BPB \\
\hline VZ0 & NB & NM & $\mathrm{Z} 0$ & $\mathrm{Z} 0$ & $\mathrm{ZO}$ & $\mathrm{Z} 0$ & Zo \\
\hline VPS & NM & $\mathrm{NM}$ & NS & $\mathrm{ZO}$ & PS & PS & PS \\
\hline VPM & NS & NS & NS & $\mathrm{Z} 0$ & PS & PS & PM \\
\hline VPB & Zo & Z0 & Z0 & $Z_{0}$ & PM & PM & PB \\
\hline
\end{tabular}

(1) 現状仕様

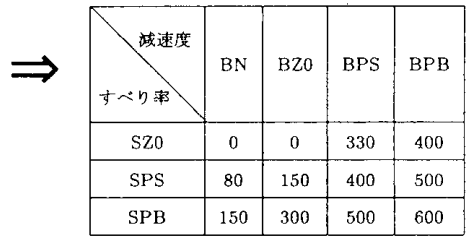

(2) 新仕様

図 6 制御規則

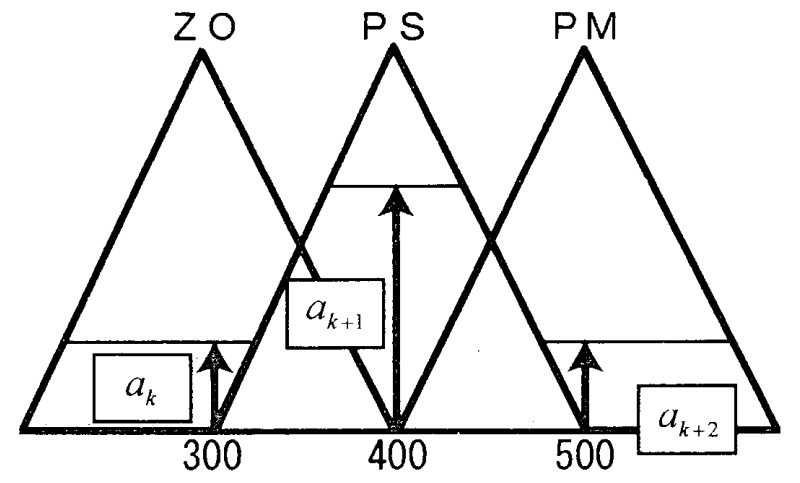

【滑走度合の算出】

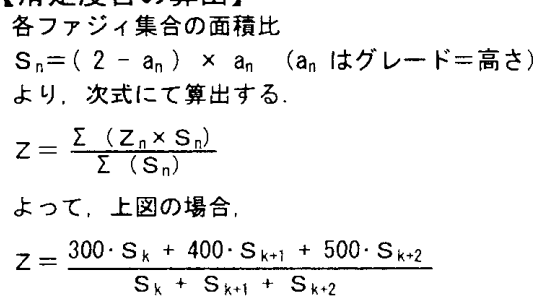

(1) 現状仕様

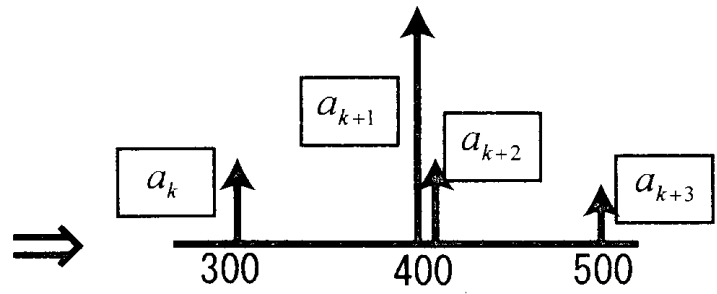

【滑走度合の算出】

$$
z=\frac{\sum\left(z_{n} \times a_{n}\right)}{\sum\left(a_{n}\right)}
$$

前件部ANDが代数積のとき，分母が1となるので， 上図の堭合。

$z=300 \cdot a_{k}+400 \cdot a_{k+1}+400 \cdot a_{k+2}+500 \cdot a_{k+3}$

\section{(2) 新仕様}

図 7 滑走度合の算出 
に緮小する（図 8 参照）。

この理由は,以下の 2 点である。

(1)現状仕様では，制御開始速度差の設定により制御 出力を大きくマスクしているなめ, ファジィ推論 による推論結果を分に活かしていない。

(2)現状付様では，不逨続な制御出力が多くなる。

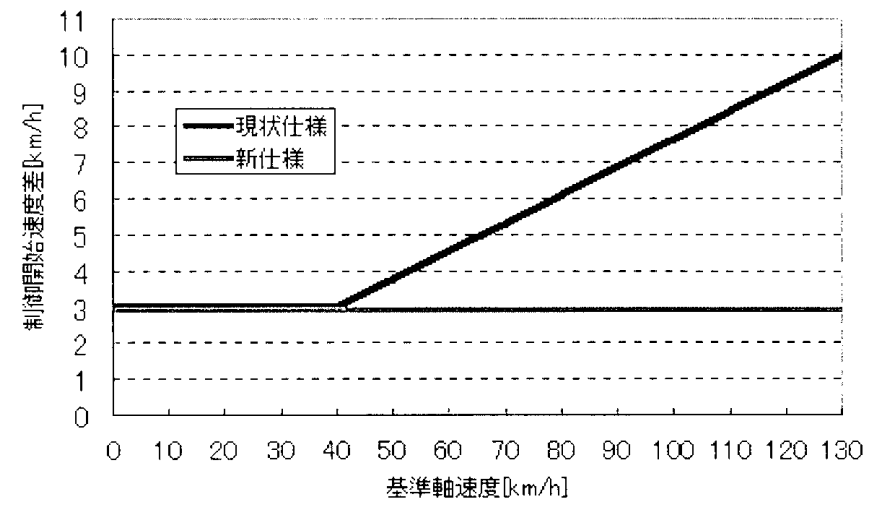

図 8 制御開始速度美比較
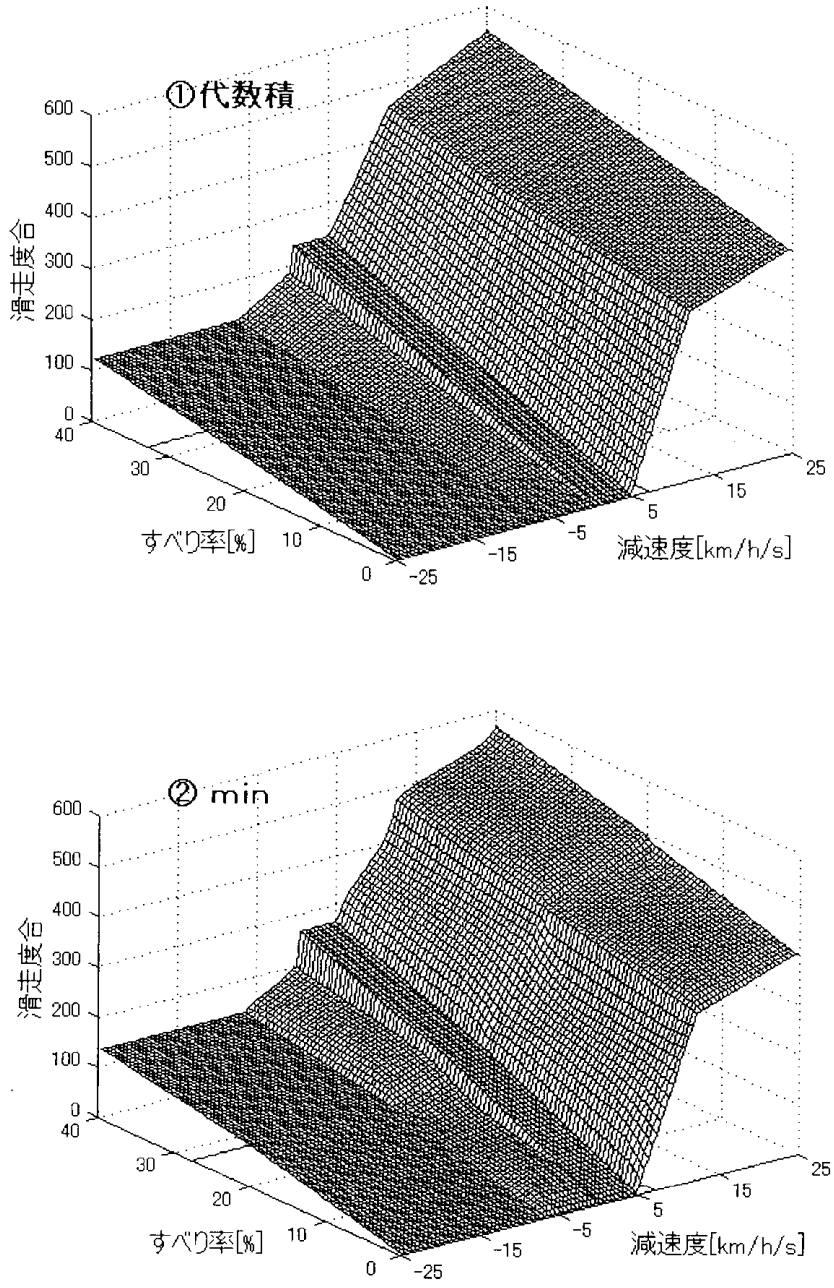

\section{4 数值シミュレーション}

\section{1 数值シミュレーションの方法および結果}

現状仕様と新仕様を数值シミュレーションにより比 較する。数值シミュレーションの制御条件を表 1 に, レール・車輪間の粘着係数モデルを四10に示す。表 1 , 四10とも，実際の在来線車闻や笑騃值に則したものと している.

なお，滑走軸が発生した場合には，後続軸の粘着係 数が增加するようなモデルとしているほか，レール・ 車輪間の接触而の粗さや温度などの要素考虑し, 各 軸の粘着係数に，個別に外乱（有色ノイズ）を加えて いる。

また，数值シミュレーション結果として，ブレーキ 距離, $\mathrm{AV}, \mathrm{RV}$ の動作回数, $\mathrm{BC}$ 压の給気総量比較を表 2 に，現状仕様に対して，3.2節で述べた新仕様の(2), (4)，(5)を個別に加味した場合のブレーキ距離を表 3 に, 現状仕様と新仕様の制御状態グラフを図11に示す。な お，各制御パラメータは，篹の在来線車弣に則した 範囲でチューニングを行っている。
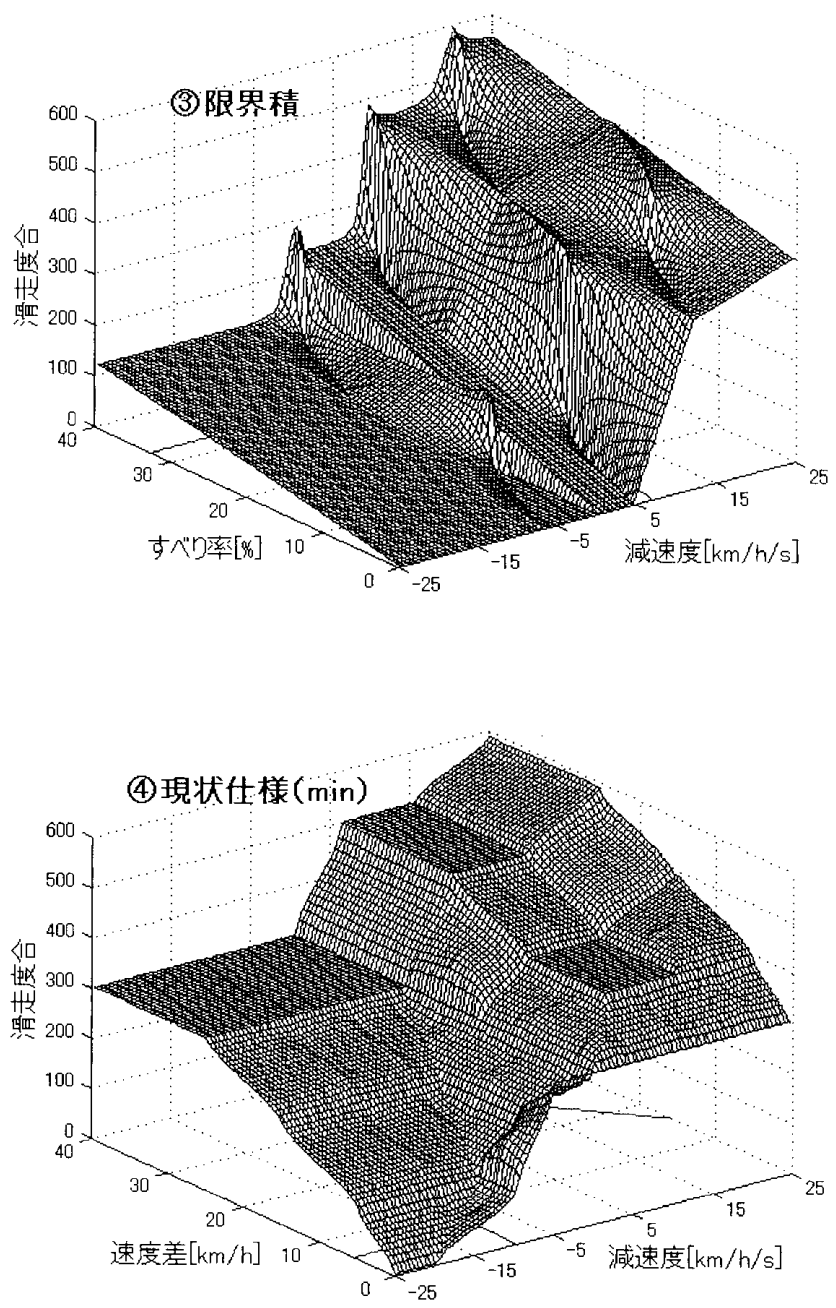

図 9 前件部 ANDに用いる演算子ごとの滑走度合 
表 1 数値シミュレーションの制御条件

\begin{tabular}{|c|c|c|}
\hline 项目 & 做 & 幽位 \\
\hline ブレーキ初速度 & 100 & $\mathrm{~km} / \mathrm{h}$ \\
\hline 型算䦌期 & 20 & $\mathrm{~ms}$ \\
\hline 輪重! & 4000 & $\mathrm{~kg}$ \\
\hline 制輪子の摩擦力/1軸 & 11000 & $\mathrm{~N}$ \\
\hline 制輪于摩擦倸数 & \multicolumn{2}{|c|}{ 一篮 } \\
\hline 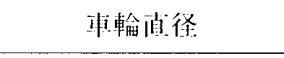 & 860 & $\mathrm{~mm}$ \\
\hline 1 軸当たりの㤨性: & 60 & $\mathrm{~kg} \cdot \mathrm{m}^{2}$ \\
\hline 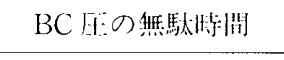 & 0.05 & s \\
\hline BC 四の情定数 & 1.2 & s \\
\hline 制御軸数 & \multicolumn{2}{|c|}{4 軸（１邽） } \\
\hline 制御方式 & \multicolumn{2}{|c|}{ 终軸 } \\
\hline
\end{tabular}

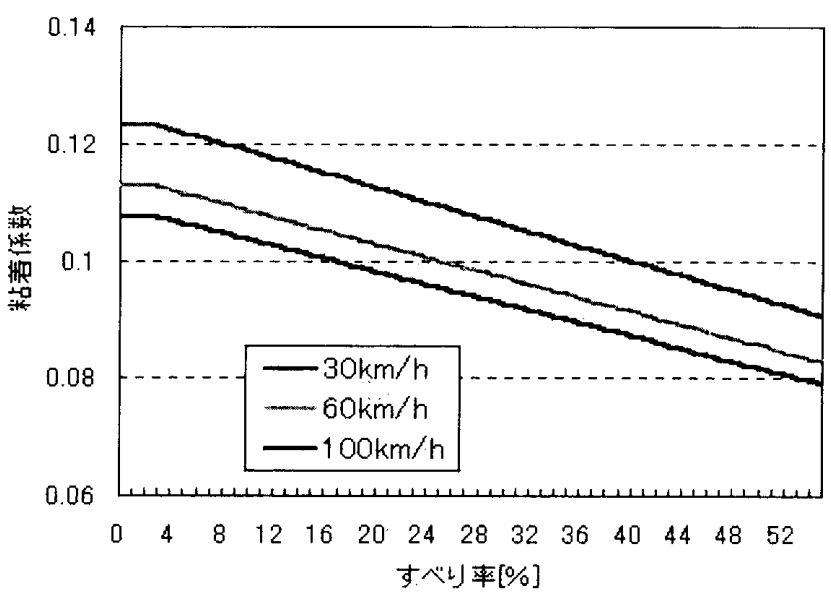

図10 数值シミュレーションの粘着係数モデル

\section{2 数值シミュレーションに対する考察}

(1) 現状仕様と比べて, 新仕様のゔが約 $8.5 \mathrm{~m}$ ブレーキ 跳離が短くなっている。新仕様ではブレーキ距離 の短縮を第一目的としていることからこのこと は現状仕様に対市る新代様の優位性をもっとも表 していると言える。

(2) 新代様のブレーキ距離が短くなった理目として, 3.2 節で述べな新仕様(1)（6)の他，後件部の設筐に 対する設訃思想の違いがある。
3.1節の手順 7 でも触れなが, 現状仕様では, 設 呠琶想として，国着防止を徹底するためにひとつ の滑歨時間を短くすることを優先し，そのために は，必ずしもファジイ推論による推論結果に忠実 に出力する必要はないものとしている，従って， 肳件㰻が，再粘着過程（VP* and $\mathrm{BN}^{*}$ ) や滑走の ない正常状態（VZO and BZO）における出力を， 保ちモードとすることで速やかな再粘着を促し， 制御開始速度帮によって，保ちモードから給気モ ードに切り替えるような制御としている。つまり， 現状仕椂は，制御開始速度差を活用することを前 提とした推諭構成で設計している。

一う，新代様では，設計思想として，ブレーキ 距離を短くすることを傯先するために無理に再粘 着を促さず，かつ，制御開始速度差に依らず，フ アジイ推論による推論結果にできるだけ忠実に出 打することを目指している。従って，再粘着過程 や证常状態における出力を，給気モードとなるよ うな推論構成で設部している。

現状代様，新仕様のこうした違いから，図11か らもわかるとおり，新仕様は無理に正常状態に戻 さず，いわゆる漸続滑走状態を許容することでレ ール・車輪間の粘着改善を四り，結果として，現 状代様に比べてブレーキ距離が短くなっているも のと考える。

（3）裴 2 より，新伐様は現状什様に比べ，BC压の給排 気童が少ない一ナ, AV, RV の動作回数は多くなっ ている.

これらのことは,ブレーキ距離を短くするには， $\mathrm{BC}$ 压をなるべく排気ささせないようにすることが有 利であり，そのためには緻密に給排気をさせるよ う，弁の動作回数を增や寸必装があることを示し ている。また，保守低減の観点では，新仕様には， 等気消費量の低減というメリットと，弁の動作[四 数增加というデメリットがあることを亦している。

(4) 表 3 より，新仕様(2)によって，前件部パラメ一夕 を 9 㑬 $\Rightarrow 5$ 個，制御規則を 28 個 $\Rightarrow 12$ 個としても，

表 2 数值シミュレーション結果

\begin{tabular}{|c|c|c|c|c|c|}
\hline & \multirow{2}{*}{$\begin{array}{l}\text { ブレーキ } \\
\text { 距䧺: }[\mathrm{m}]\end{array}$} & \multicolumn{3}{|c|}{$\mathrm{AV}, \mathrm{RV}$ の動作泀数 [回] } & \multirow{2}{*}{ 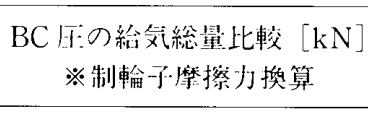 } \\
\hline & & $\mathrm{AV}$ & RV & 合部 & \\
\hline 現状代様 & 375.6 & 45 & 35 & 80 & 89.4 \\
\hline 新仕様 & 367.1 & 68 & 24 & 92 & 62.1 \\
\hline
\end{tabular}

表 3 現状仕様に刘して新代様(2)，(4)，(5)を個别に加味した場合のブレーキ距離

\begin{tabular}{|c|c|c|c|c|}
\hline & 現状珄栐 & 兒状代樣＋新代様(2) & 現状仕様＋新仕㥞(4) & 現状代様＋新仕様(5) \\
\hline ブレーキ趾離 $[\mathrm{m}]$ & 375.6 & 374.4 & 375.6 & 370.9 \\
\hline
\end{tabular}



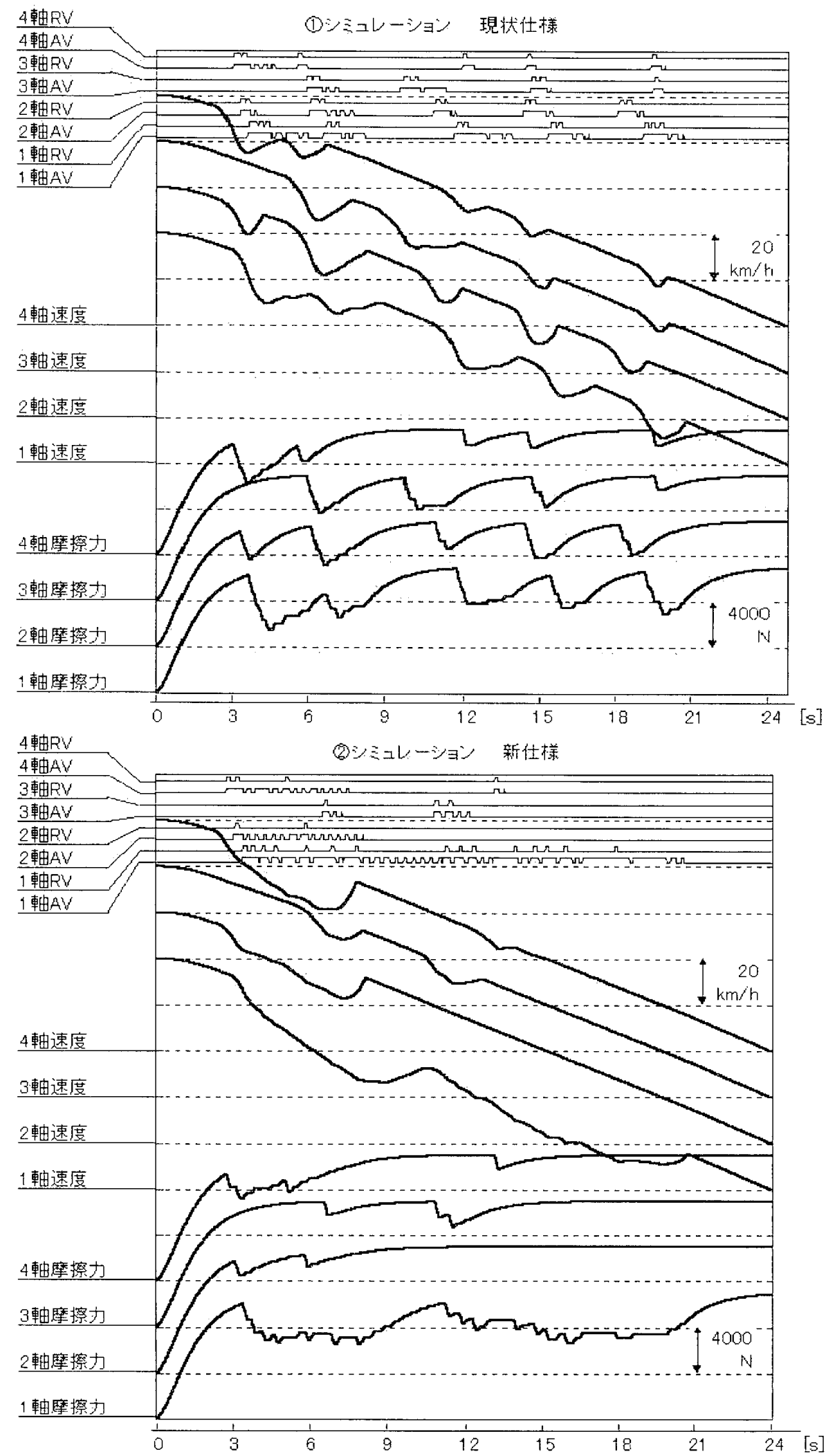

図11 AV, RV の動作回数, 制輪子の摩擦力, 速度の比較（数值シミュレーションチャート）

また, 新仕様(4)，(5)によって, 前件部 ANDの演算 子を代数積に，後件部をシングルトンとして簡略 化推論法を用いても，現状仕様よりもブレーキ距 離が延びていないことがわかる。このことは，新 仕様では制御性能を下げることなく，チューニン グの容易化と計算量の低減を図っていることを示
している.

以上より，新仕様は，現状仕様に比へ，弁の動作回 数は增加するものの, ブレーキ距離を知縮させたうえ で, 計算量の低減，チューニングの容易化および空気 消費量の低減を四っていることがわかる． 


\section{5 おわりに}

本論文ではファジィ推論を舫いたABSに対して、ブ レーキ距離の短維を第一目的としな新なな制御構成(新 仕様）を提案し，数估シミュレーションによって，䉼 仕様が現状仕様に比べてブレーキ趾離の短緮が枢れる ことを示しなこのことから，新仕様は，笗全耐およ び輸送サービス伯に大きく然りすることが期街できる。

また，新仕様では，ブレーキ趾離の知秎な゙けでなく， 䛨算量，チューニングに抢いて，現状仕様よりも優位 性を与えることができた。これらのことは, ABSの制 御プログラムの簡素化とともに, ABS 存使用開始する 前に行う現車試娩の簡略化が図㣗ることを示しており， ABSの品質管理面に対古る䐝献が大きいと言える。

今後は，現本武騃によって新什様の制御性能を惑部: していく.

\section{謝 辞}

本砸究を進めるにあたり協力いただいた，財団法人 鉄道総合技術研究所 OBの大山忠犬比ならびに同研究 所ブレーキ制御研究窒备位に対し，心より感謝の意を 装します。

\section{参 考 文 献}

[1] 嫶罗: New Anti-Skid Control System Applying Fuzzy Control Technique, 鉄道高速化国際会緒諭 文集, Vol.2, No.2, pp.128-222，1993-11

[2] 嫶見，板野：FUZZY 制御怘时 ANTI-SKID 制御

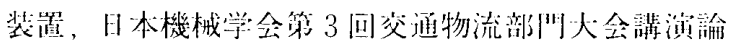
文集, No.940-57, pp.237-240，1994-12

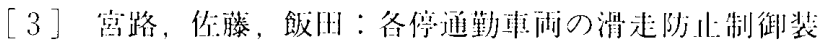

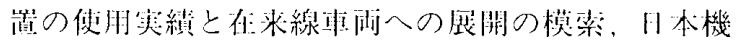

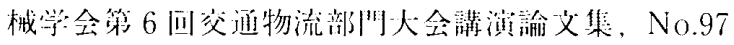
-13, pp.111-114, 1997-7

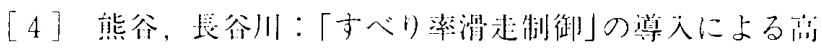
速化・高減速度化, RRR, Vol.53, No.10, pp.18$21,1996-10$

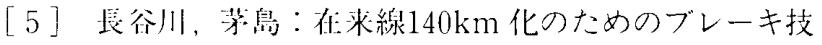
術，鉄道総研青告，Vol.13，No.10，pp.35-40， 1999-10

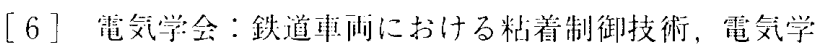

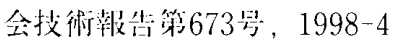

［7］㧹谷，琵谷川，川几：本輪滑走およびフラット発生 のメカニズム, 鉄道総研報告, Vol.5, No.7, pp.3341, 1991-7

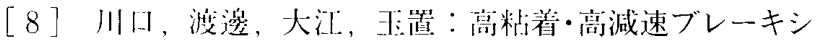
ステムの鬥発，日本機械学会筙3 回交通物流部門大 会諢演論文集，No.940-57, pp.241-244，1994-12

[9]四方，增見，增田：ファジィ制御を用いた滑走再粘

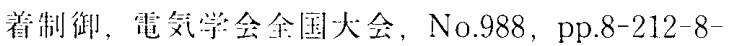
213, 1992-3

[10] M. Boiteux : Les antienrayeurs modernes Principles constructifs, Revue generale des chemins de fer, Vol.105, No.61, pp.73-81, 1986-2

[11] M. Boiteux : Le probleme de l'adherence en freinage, Revue generale des chemins de fer, Vol. 105, No.61, pp.59-72, 1986-2

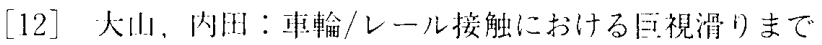
の粘着力の举動, 日本機械学全墖文集60巻574号 C 編, pp.2096-2102, 1994-6

[13] 大山：粘着の活，レールアンドテック出版，2002-12

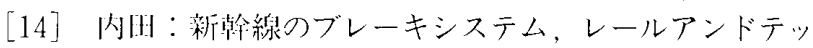
ク虫版，2001-3

[15] 日本ファジィ学会：講夾ファジィ籍 2 替「ファジィ集 合」、日刊工業新閉社，pp.187-226，1992-12

[16]水本：ファジイ制御の改善法(IV)，第 6 四 Fuzzy System Symposium, pp.9-13, 1990-9

[17] 水本，山目：ファジイ推諭法による補間 (2)、第 8 回 Fuzzy System Symposium, pp.217-220, 1992-5

(2003华: 8 月 10 日 受付)

(2004年: 5 月24日 採録)

[1!

干185-8540 東宗都国分考术2-8-38

財団法人 鉄道総合技術研究所

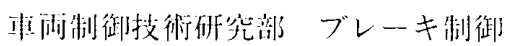

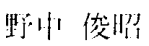

TEL : 042-573-7286

FAX : 042-573-7259

e-mail : nonaka@rtri.or.jp toshiakinonaka@odakyu-dentetsu.co.jp 


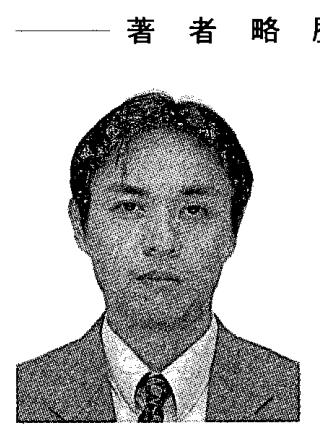

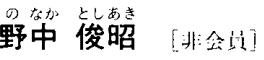

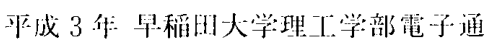
偣学科卒, 平成 5 年. 同大大学院理工学研 究科修了. 闹年:小目急笔鉄株式会社入社, 平成14年：鉄道総合技術研究所一派遣と なり，現在に至る。鉄道事雨のファジィ ABS 制御に関する研究, 鉄道車芮の設部 に彷事。日本機械学会会具。

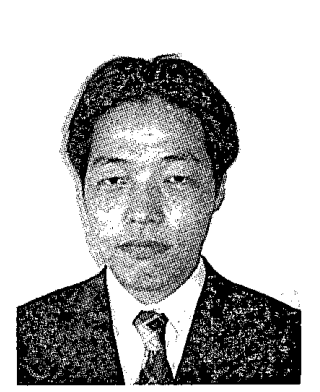

\section{吉川広 [州丟目}

平成 6 年 大阪甫立大学理学部化学科 卒。平成 6 件株式会社カコテクノス入社, 闹俳三菱電機株式会社へ派遣となり，現 在に至る。鉄道本陑のファジィABS 制御 に関する研究，鉄道車闬のブレーキに関

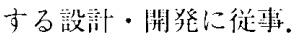

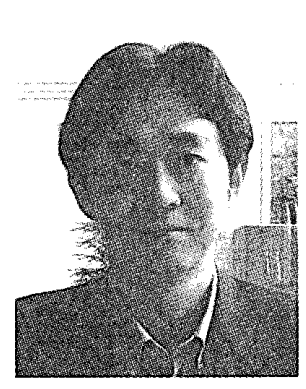

\section{遠藤靖典〔西会训}

平成 2 年 早稻时大学理工学部電子通 信学科卒, 倠成 7 年: 同大大学院理厂学研

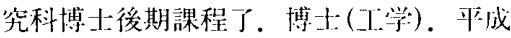

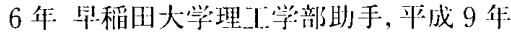
來海大学:工学部講阨, 平成13年: 筑波大学

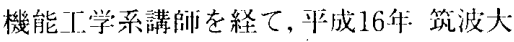
学大学院システム情報工学研究科助教授 となり，現在に篗る。鉄道車雨のファジィ ABS 制御に関寸る研究・ファジィ理論を 用いたシステムの変動解析に関する研究, クラスタリングに関する研究に御事。管 子情趣通信学全平成 5 年度諭文賞, 闹学: 全闰瓜腐米澤ファウンダーズ・メダル受 嘪記念特別賞, 同学会平成 6 年度学術奖 阙賞，日本ファジイ学食平成 8 年度奖厉 真备受賞. 日本知能情報ファジィ学食,

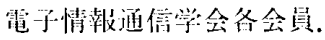

\section{Improvement of Control Performances of Anti-Lock Braking System with Fuzzy Reasoning for Rolling Stock}

by

\section{Toshiaki NONAKA, Yasunori ENDO, Hroshi YOSHIKAWA}

\section{Abstract :}

From the viewpoint of safety and noise reduction, the study on anti-lock braking systems of rolling stock is very important. But, the skid of wheels of rolling stock is strongly uncertain phenomenon so that it is too hard to control it and there are no general guides to construct anti-lock braking systems. By the way, it is well-known that fuzzy reasoning is available to controlled systems with strong uncertainty. Thus, we can consider that fuzzy reasoning is also available to braking systems of rolling stock. In this paper, we propose a new anti-lock braking system with fuzzy reasoning for rolling stock in order to shorten braking distance. The proposed system can realize not only shortening of braking distance but also reduction of calculational volume and facilitation of tuning. Moreover, we show that the proposed system can shorten braking distance through numerical simulation.

Keyword:

Contact Address : Toshiaki NONAKA

Brake Control,Railway Technical Research Institute, Tokyo 185-8540, Japan

TEL : :042-573-7286

FAX : 042-573-7259

e-mail : nonaka@rtri.or.jp

toshiakinonaka@odakyu-dentetsu.co.jp 